\title{
Ecology and the challenge of a multifunctional use of soil
}

\author{
Patrick Lavelle(1)
}

(1)Institut de Recherche pour le Développement, Centro Internacional de Agricultura Tropical (Instituto TSBF), Apartado aereo 6713, Cali, Colombia. E-mail: patrick.lavelle@bondy.ird.fr

\begin{abstract}
Soil zoology and soil ecology have become very active fields of research since the early 1990 s. A search in the ISI Web of Science databases showed a steady increase in publications about that theme over the last two decades, and 3,612 bibliographic references were found for that theme for the period of 2004 to 2008. The researches covered mostly soil environmental issues, toxicology and ecology. The issue of theoretical development in soil ecology is discussed, and arguments are presented against the idea that the soil ecology theory is deficient. Finally, the need for a general model of soil function and soil management is discussed and some options are presented to reach this goal.
\end{abstract}

Index terms: auto organization, panarchy, soil ecology, soil zoology.

\section{Ecologia e o desafio do uso multifuncional do solo}

\begin{abstract}
Resumo - A zoologia e a ecologia do solo tornaram-se áreas de pesquisa muito ativas a partir do início da década de 1990. Uma busca realizada na base de dados ISI Web of Science mostrou um gradual aumento no número de publicações sobre o assunto nas últimas duas décadas, tendo sido encontradas 3.612 referências bibliográficas para o período de 2004 a 2008. As pesquisas abordaram principalmente assuntos ambientais, toxicologia e ecologia. O desenvolvimento da teoria em ecologia do solo é discutido, e são apresentados argumentos contra a ideia de que existe deficiência na teoria em ecologia do solo. Finalmente, é discutida a necessidade de um modelo geral de funcionamento e manejo do solo, e são apresentadas algumas opções para atingir esse objetivo.
\end{abstract}

Termos para indexação: auto-organização, panarquia, ecologia do solo, zoologia do solo.

\section{Introduction}

Soil zoology and ecology cover a fast-growing field of scientific research, from basic biology and its molecular developments, through ecology and environmental sciences, and the still-burning question of the dynamics and functions of biodiversity and the threats to ecosystem services. The $\mathrm{XV}^{\text {th }}$ Colloquium on Soil Zoology held in Curitiba (Brazil) in September 2008 provided an opportunity to review the advances in research and identify forthcoming challenges in soil ecology.

This paper describes the scientific fields and questions currently covered by this discipline at the onset of the $21^{\text {st }}$ century, and addresses the status of soil ecology in general science, highlighting the peculiarities of the discipline within mainstream ecology, and as a field where general ecological laws often do not apply. It also explains the need for a shift in our conceptual background, for the development of truly adapted paradigms and theories that address soil function in its entirety and are linked with social and economic sciences, in order to identify and implement the best possible compromises for soil management.

\section{Scientific domains and production}

Scientific production in soil zoology has increased exponentially since the early 1990s (Figure 1). A simple search of the ISI Web of Science system performed with the keywords soil fauna, soil invertebrates, earthworms, termites, soil ants, Collembola and soil Acari revealed 3,612 references for the 2004-2008 period. These could be distributed within 29 variably overlapping "thematic fields" (Figure 2). Biology and soil issues were the most commonly found keywords, just before toxicology and environmental sciences. This highlights the priorities set by soil ecologists on issues of soil management and conservation. Ecology followed, with significant contributions to community ecology, biodiversity, models and several related themes 
on trophic and nontrophic relationships. Microbiology, landscape ecology and global change were other themes with important inputs.

Another interesting issue is the kind of journals in which soil zoologists publish their work. The largest proportion was published in soil biology and ecology journals (736), followed by ecotoxicology (206), general ecology (130), microbiology (60), and soil science (50). While publications were dispersed among a very large number of journals, another remarkable feature is the very low number of papers published in the four major generalist scientific journals: Science (2), Nature (1), Proceedings of the National Academy of Sciences (4) or Trends in Ecology and Evolution (1). This feature has lead several authors (Barot et al., 2007; Andrén et al., 2008) to argue that soil ecology is weak at producing general paradigms and theories on which to base its own research and as a source of further inspiration for non-soil ecologists and other scientists.

Nevertheless, this situation may mainly reflect biases of the top generalist journals towards selected types of research and themes that they consider of a greater general interest.

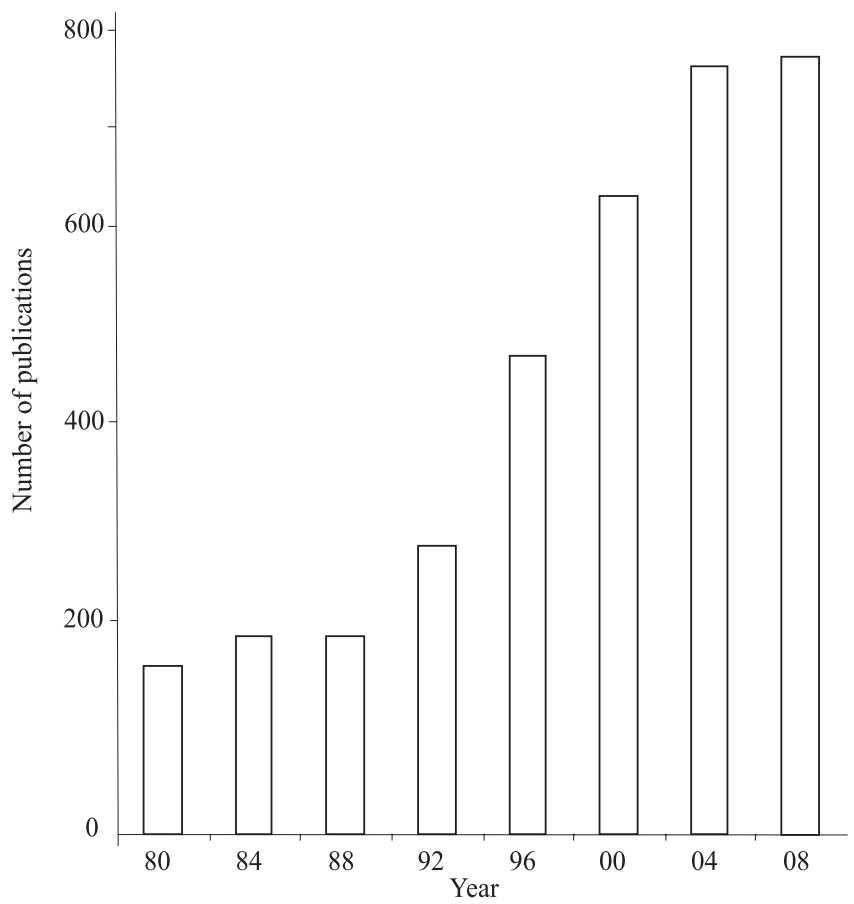

Figure 1. Average yearly number of publications on soil invertebrates (source ISI Web of Science; keywords: soil fauna, soil invertebrates, earthworms, termites, soil ants, Collembola and soil Acari).

\section{Theoretical developments in soil ecology}

Soil ecology has a long tradition of scientific production and many great names associated to it. Aristotle, who once described earthworms as the "intestine of the Earth", may not have acknowledged himself as a soil ecologist; but perhaps Darwin would have, given his life-long work on earthworms (Darwin, 1881), considered the milestone for future studies on soil ecosystem engineers. Over the last century, scientists have regularly added their contributions to the building of soil ecological theory (Bornebusch, 1930; Gisin, 1943; Omodeo, 1952; Jongerius, 1960; Wallwork, 1970; Bouché, 1972; Swift et al., 1979; Bal, 1982; Satchell, 1983), and a few recent textbooks synthesize the accelerated development of soil ecology in the last 20 years (Gobat et al., 1998; Lavelle \& Spain, 2001; Coleman et al., 2004; Bardgett et al., 2005).

Soil science and soil ecology in particular deal with complex systems, in which biological interactions are highly constrained by a number of environmental factors. In soils, competition for the capturing of resources, for long a major issue in mainstream ecology (actually largely dominated by above-ground vertebrate, insect and plant studies) is only one of these constraints, probably not the major one. Mutualism is thought to be a widely spread form of interaction among soil organisms in the use of generally low-quality resources (Lavelle, 1997; Wall \& Moore, 1999). Physical constraints of the environment, like moving in a compact environment and facing often rapidly variable moisture conditions, impose major restrictions on soil organisms. Therefore, ecosystem engineering that helps adapt to these constraints is a major process, whereby ecosystem engineers create suitable conditions for the existence of other groups, often based on mutualist relationships.

Competition and food-web effects observed in experiments and under specific field conditions may not be a dominant process, but rather act as secondary, although important regulators to adjust microbial activity and processes at the meso-aggregates scale (hundreds of micrometers to milimeters). Ecosystem engineers, when they are present, tend to regulate processes via predominantly mutualist interactions at the scales of their functional domains $\left(10^{-2}\right.$ to $\left.10^{-1} \mathrm{~m}\right)$ and of the ecosystem $\left(10^{1}\right.$ to $\left.10^{2} \mathrm{~m}\right)$, the ones that matter for the delivery of ecosystem services (Lavelle et al., 2006). 
Furthermore, observations of spatial partitioning of populations that are said to support the hypothesis of a competitive exclusion among species of ants or earthworms (Albrecht \& Gotelli, 2001; Decaëns et al., 2008) might as well be interpreted as the result of a cooperation across time in still unidentified succession processes. Bernier \& Ponge (1994) showed that patches where earthworms do occur in alpine spruce forests actually are in a stage of the natural succession where litter accumulated and decomposed by fungi and arthropods during more than 60 years has become a suitable resource for earthworms. The absence of earthworms in other places where succession is at other stages is by no means due to their exclusion by the arthropods that colonize the litter. These arthropods and the associated fungal microflora are

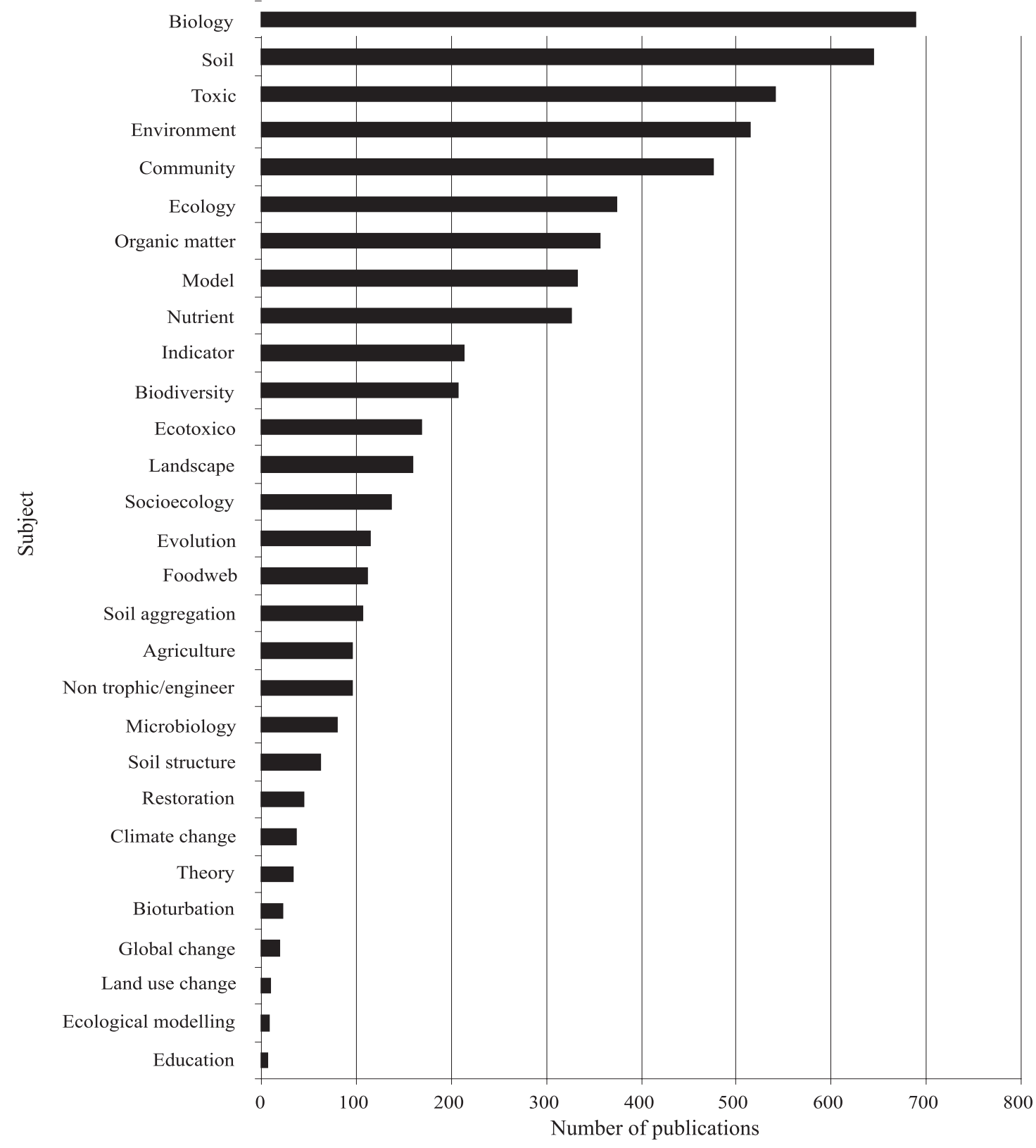

Figure 2. Publication subjects for the period 2003-2008 (note that one publication may fall under several keywords). Source: ISI Web of Science. 
actually participating in a maturation process that will transform litter into a suitable food for earthworms at a later stage.

Another example of disjointed distributions that might be misinterpreted is provided by endogeic earthworms. In the Lamto savannah, two functional groups of endogeic earthworms that exhibit clear opposite patterns of spatial distributions seem to operate successively in time, in patches of about $20-30 \mathrm{~m}$ in diameter. While compacting species eat and transform small aggregates into larger ones, decompacting species feed on large aggregates that they split into smaller ones while adding organic matter, probably from decomposing root material (Blanchart et al., 1997; Barot et al., 2007). Spatial "exclusion" in that case might well be the manifestation of complementary functions that allow both functional groups to alternate their spatial distributions in time. This succession process would ultimately affect other larger-scale properties of the soil, such as hydric functions and $\mathrm{C}$ sequestration in aggregates.

Background for research development on nontrophic relationships and small-scale successional processes in ecosystems, which would form the conceptual basis for these findings, is still very limited in current ecology textbooks, although the theme is now in rapid development. Soil ecologists have dedicated major efforts to the description of patterns, an important step towards the formulation of theories in this respect. These studies are generally not published by high-impact generalist journals that tend to reflect the dominant issues, and favour papers presenting mechanisms rather than patterns and aboveground rather than belowground organisms, with few exceptions.

Although one can observe the rapid development of concepts and theories around the paradigm coined by Jones etal. (1994) as "ecosystem engineers", remarkable practical and theoretical bases for this concept can be found in the admirable work of Bal (1982), who, among many others, explained how the progressive building of biogenic structures by soil ecosystem engineers ends up modifying humus forms and soil function. This would inspire further works linking ecological succession processes to changes in soil habitat and soil resources (Bernier \& Ponge, 1994), and announce the development of the concept of functional domains of ecosystem engineers in soils (Lavelle, 2002) and the recognition that self organization based on mainly nontrophic interactions probably explains most features in soil function (Young \& Crawford, 2004; Lavelle et al., 2006). These theoretical developments, rooted in slow and time-consuming observations and reflexions on soil complexity, have had little echo in mainstream ecology, not to speak of soil science itself. They are, however, the basis for a next step of ecological theory that will give more attention to environmental constraints, nontrophic and mutualistic relationships, and to the consideration of larger scales, especially the landscape dimension of processes.

Ecological complexity will hardly be solved by reductionist approaches. While the facts described in any well-conducted laboratory or field experiment are undoubtedly true, their ability to represent real nature is questionable. For instance, most microcosm studies that use de-structured soil environments and communities for example, the excellent study by Heemsberger et al. (2004) - probably simulate ecosystem conditions of a reorganization phase following a great disturbance, that is, the $\alpha$ phase of the adaptive cycle (Gunderson \& Holling, 2002). The total disruption of soil organization, removal of invertebrates from habitats they might have constructed, and from the organisms with which they might have sophisticated positive interactions (that experimental conditions ignore), actually simulates conditions that are rarely found in the real world.

This frequent bias in experimental approaches and the hyper-specialization in research topics has led to an understanding that trophic relationships are a dominant feature in the regulation of soil communities and, hence, of their effects on nutrient cycling. Studies supporting this idea were certainly done with the best quality observations, technical and modelling approaches, but they may concern mostly conditions in which only this type of interaction would operate. They describe mostly situations (deserts, arable land) in which soil ecosystem engineers are rare, or artificially simulate their effects without acknowledging them. This is the case for many microbial activity assessments in laboratory conditions in which sieving and rewetting dry soil imitates the effect of ecosystem engineers when they redistribute inactive microorganisms, bringing them in contact with the organic substrates they degrade - see the "Sleeping Beauty paradox", Lavelle et al. (1995). The mechanisms thus described do exist, but their overall importance is probably less general than it is currently acknowledged in papers published by generalist 
ecological journals. They probably operate as fine regulators inside the functional domains organized by large ecosystem engineers (Lavelle \& Spain, 2001).

Reconciling reductionist approaches with holistic views seems to be a recurrent problem for disciplines that deal with complexity. In the case of ecology, reductionism is favoured by the better treatment it gets from the evaluation system and the journals in general. When reductionist approaches have reached their limits, or temporarily answered a given question, other levels of complexity are introduced into the models. This is how stoichiometry, a familiar question for soil microbiologists and specialists of decomposition processes (Swift et al., 1979), has strongly irrupted into general ecology (Sterner \& Elser, 2002); the same occurs now, when nontrophic interactions are being finally considered, whereas only trophic ones had been considered for decades (Jones et al., 1994; Davis et al., 2004; Martinez et al., 2006; Goudard \& Loreau, 2009).

\section{Soil zoology/ecology and the global environment crisis: the need for a renewed conceptual approach}

Soils are the basis for the production of important ecosystem services, many of them experiencing a process of degradation (Millennium Ecosystem Assessment, 2005; Lavelle et al., 2006). There is a need for general models that integrate all soil elements and functions to resolve new and urgent questions regarding soil management.

Dokuchaev (1889) and soil science forerunners (Jenny, 1941; Duchaufour, 1960) have shown that soil formation and function depend on the interaction of four fundamental elements: geological substrate, climate, organisms and time. Most studies and theories developed during the twentieth century describe processes and interactions based on this paradigm. However, the overall soil function model has not progressed much and research has focused mostly on each one of the components, overlooking the global framework (Lavelle, 2000). The urgent need for promoting holistic (integrated) soil management approaches, which represent the best commitment with resource conservation and sustainable production of environmental goods and services, requires a conceptual framework that is at the same time more detailed and yet broader than Dokuchaev's original frame of reference: a soil function model that simultaneously takes into account organisms, physical soil structures and processes and their interactions throughout space and time. This model would allow the evaluation of soil integrity and the determination of the consequences of external interventions or changes to soils: a resource management model that integrates soils, environment, human societies and economic systems. It would consider the best compromises between the delivery of diverse goods and services, and the needs and situations of the social and economic fields.

General soil function and pedogenesis conceptual models based on the self-organization theory (Lavelle et al., 2006; Targulian \& Krasilnikov, 2007) have recently been proposed. Soil is made of functional units organized at discrete scales, with boundaries within which organisms interact and build structures that influence the rates and pathways of processes. These self-organized systems generally have feedback effects on the external constraints, and they are in a metastable state, as their existence depends on biological activities. A simple example of such a system is the rhizosphere, where roots interact with a community of microorganisms and invertebrates that has been selected through ecosystem engineering effects; rhizospheres have clear boundaries, within which interactions among organisms create structures (root-formed aggregates) and improve the fitness of all participants (plant nutrient uptake through interactions with mycorhizae and $\mathrm{N}$-fixing microorganisms; activation and selection of rhizoplane microorganisms by root exudation). Rhizospheres exist as long as root does; they are, therefore, metastable structures.

Such discrete functional units interact at a given scale. This is, for example, the case of rhizosphere systems that interact with drilospheres of earthworms or termitospheres of termites (Brown et al., 2000). Similarly organized systems exist at smaller or larger scales, forming a suite of embedded systems. Five such scales can be observed in soils from the smallest scale of 1, microbial colonies and their microstructures (biofilms, microassemblages of clay particles); to 2 , intermediate scale aggregates $(20-50 \mu)$, where mostly foodweb processes operate; 3 , where functional domains of ecosystem engineers are found (Lavelle, 2002); 4, soil horizons comprised of assemblages of ecosystem-engineer functional domains and some nonbiological structures; and 5, soil catenas at the landscape level.

The Panarchy Theory of Gunderson \& Holling (2002) adds two complementary elements to the 
self-organizing soil model of Lavelle et al. (2006). First, it states that self-organized systems (SOS) have a dynamic over time that makes them undergo four successive phases during which the connectivity (i.e., intensity of relationships among organisms) and potential (the amount of resources available in the system) experience changes: 1 , an $\alpha$ organization phase, starting from the elements of biodiversity, materials (organic matter, mineral particles), and sources of energy of nutrients available within the boundaries in which the SOS is to be formed - for example, a root that grows in the soil selects the microflora by activating it in a selective way through the production of exudates; it also creates a specific habitat for micro and mesofauna by aggregating the surrounding soil, using the mineral elements as well as the porosity that exists in the microsite, and the organic matter and nutrients that can be used by the root, or the mycorrhiza growing on it; 2 , a $r$ rapid growth phase, corresponding to the expansion of the system, which increases its connectivity as it becomes more complex by increasing its biodiversity and the diversity of the physical structures created; 3 , a $\mathrm{K}$ conservation phase when the system has reached maturity and remains in a metastable regime; 4 , a $\Omega$ phase of destruction of the system by external events (physical destruction and/or dispersion of the structures created, or death of the main engineer organism that was producing the structures and selectively activating the microorganisms present).

Each self-organized system is therefore represented as a horizontal eight-shaped Figure that illustrates respective changes in the connectivity (horizontal axis) and potential (vertical axis) of the system.

The Panarchy Theory also assumes that the ecological systems, as well as social and economic systems, have the same structures, based on self-organized systems, embedded within one another through a hierarchy of temporal and spatial scales. The units that comprise these systems have their own dynamics as per the adaptive cycle model.

Several authors have demonstrated the value of the Panarchy Theory as a framework to explain certain complex events in which the interaction among ecosystems, societies and economies have caused catastrophic phenomena and the vulnerability of the environment (Dorren \& Imeson, 2005; Fraser et al., 2005; Dorren \& Berger, 2006; Grofmann et al., 2006). For example, the Irish food crisis between 1845 and 1850 illustrates how social and economic forces created the vulnerability of the ecologic/economic system, leading to a situation where farmers depended entirely on potato production for their nourishment.

The agroecosystems developed in those days had properties that are characteristic of vulnerable systems. Potato fields were very close to each other (high connectivity), the biodiversity was very scarce, and much biomass was being produced (high "potential"), all of which made these systems an attractive objective for opportunistic herbivorous pests. A series of social, demographic and economic factors generated this vulnerability (Fraser, 2003).

\section{Conclusions}

Soil ecology is a very active field of research, and it will have a critical role in solving part of the problems generated by the global environment crisis.

The self-organizing soil theory and its generalization into the Panarchy Theory provide a unique theoretical framework to integrate in one entity all the organisms and their interactions, the physical structures that they create and/or in which they live, and the processes that take place within the structures throughout the scales of time and space identified in the field.

The systems thus described have a series of properties that need to be considered when trying to explain processes that are not yet well understood - for example, the dynamics of soil aggregation -, or in avoiding sudden deterioration (erosion, pests). Particularly interfaces among elements in space and in time are the privileged places/moments where and when interactions can have a strong impact on the overall functioning of the system. The identification of these interfaces will enable locating precisely, in space and time, the process that is playing a critical role under specified conditions in the survival dynamics of the system as a whole.

The model facilitates diagnosis at precise scales through the use of structure and/or function indicators. These indicators should be clearly characterized according to their use for characterizing the state of structures, or of processes conducted at the scale indicated for the measurement; or for characterizing the quality of the interfaces among different localized systems at a same scale, or between scales.

In further stages, simulation models of the whole system should be built in order to provide scenarios on which to base soil management, their dependence and their effects on ecological, sociological and economic processes at different scales. 


\section{References}

ALBRECHT, M.; GOTELLI, N.J. Spatial and temporal niche partitioning in grassland ants. Oecologia, v.126, p.134-141, 2001.

ANDRÉN, O.; KIRCHMANN, H.; KATTERER, T.; MAGID, J.; PAUL, E.A.; COLEMAN D.C. Visions of a more precise soil biology. European Journal of Soil Science, v.59, p.380-390, 2008.

BAL, L. Zoological ripening of soils. Wageningen: Pudoc, 1982. 375 p.

BARDGET, R.D.; USHER, M.B.; HOPKINS, D.W. Biological diversity and function in soils. Cambridge: Cambridge University, 2005. 411p.

BAROT, S.; BLOUIN, M.; FONTAINE, S.; JOUQUET, P.; LATA, J.C. A tale of four stories. Soil ecology, theory, evolution and the publication system. PLoS ONE, v.2, 2007. Doi: 10.1371/journal.pone.0001248.

BERNIER, N.; PONGE, J.F. Humus form dynamics during the silvigenetic cycle in a mountain spruce forest. Soil Biology and Biochemistry, v.26, p.183-220, 1994.

BLANCHART, E.; LAVELLE, P.; BRAUDEAU, E.; LE BISSONAIS, Y. ; VALENTIN, C. Regulation of soil structure by geophagous earthworm activities in humid savannas of Cote d'Ivoire. Soil Biology and Biochemistry, v.29, p.431-439, 1997

BORNEBUSCH, C.H. The fauna of forest soil. Forsögswaesen Copenhagen, v.11, p.1-244, 1930.

BOUCHÉ, M.B. Lombriciens de France: écologie et systématique. Paris: Institut National de Recherches Agronomiques, 1972. 642p.

BROWN, G.G.; BAROIS, I.; LAVELLE, P. Regulation of soil organic matter dynamics and microbial activity in the drilosphere and the role of interactions with other edaphic functional domains. European Journal of Soil Biology, v.36, p.177-198, 2000.

COLEMAN, D.C.; CROSSLEY, D.A.; HENDRIX, P.F. $2^{\text {nd }}$ ed. Fundamentals of soil ecology. San Diego: Academic Press, 2004. 386 .

DARWIN, C. The formation of vegetable mould, through the action of worms with observations on their habits. London: Murray, 1881.

DAVIS, A.J.; LIU, W.C.; PERNER, J.; VOIGT, W. Reliability characteristics of natural functional group interaction webs. Evolutionary Ecology Research, v.6, p.1145-1166. 2004.

DECAËNS, T.; MARGERIE, F.; AUBERT, M.; HEDDE, M.; BUREAU, F. Assembly rules within earthworm communities in NorthWestern France: a regional analysis. Applied Soil Ecology, v.39, p.321335,2008

DOKUCHAEV, V.V. The zones of Russia. Moscow: Akademy Nauk, 1889.

DORREN, L.K.A.; BERGER, F. Panarchy and sustainable risk prevention by managing protection forests in mountain areas. In: AMMANN, W.J.; DANNENMAN, S.; VULLIET, L. (ed.). Risk21: coping with risks due to natural hazards in the $21^{\text {st }}$ century. London: Taylor \& Francis, 2006. p.203-213.

DORREN, L.K.A.; IMESON, A.C. Soil erosion and the adaptive cycle metaphor. Land Degradation \& Development, v.16, p.509-516, 2005.

DUCHAUFOUR, P. Précis de pédologie. Paris: Masson, 1960. 438p.
FRASER, E.D.G. Social vulnerability and ecological fragility: building bridges between social and natural sciences using the Irish potato famine as a case study. Conservation Ecology, v.7, 2003. Available at: < http:// www.ecologyandsociety.org/vol7/iss 2/art9/>. Accessed on: 11 Sept. 2009.

FRASER, E.D.G.; MABEE, W.; FIGGE, F. A framework for assessing the vulnerability of food systems to future shocks. Futures, v.37, p.465-479, 2005.

GISIN, H. Ökologie und Lebensgemeinschaften der Collembolen im schweizerischen Exkursionsgebiet Basels. Revue Suisse de Zoologie, v.50, p.131-224, 1943.

GOBAT, J.M.; ARAGNO, M.; MATTHEY, W. Le sol vivant: base de pédologie, biologie des sols. Lausanne: Presse Polytechnique et Universitaire Romande, 1998.

GROFFMAN, P.; BARON, J.; BLETT, T.; GOLD, A.; GOODMAN, I.; GUNDERSON, L.; LEVINSON, B.; PALMER, M.; PAERL, H.; PETERSON, G.; POFF, N.; REJESKI, D.; REYNOLDS, J.; TURNER, M.; WEATHERS, K.; WIENS, J. Ecological thresholds: the key to successful environmental management or an important concept with no practical application? Ecosystems, v.9, p.1-13, 2006.

GOUDARD,A.; LOREAU, M. Nontrophic interactions, biodiversity, and ecosystem functioning: an interaction web model. American Naturalist, v.171, p.91-106, 2008.

GUNDERSON, L.H.; HOLLING, C.S. Panarchy: understanding transformations in human and natural systems. San Francisco: Island Press, 2002.

HEEMSBERGEN, D.A.; BERG, M.P.; LOREAU, M.; VAN HAL, J.R.; FABER, J.H.; VERHOEF, H.A. Biodiversity effects on soil processes explained by interspecific functional dissimilarity. Science, v.306, p.1019-1020, 2004.

JENNY, H. Factors of soil formation: a system of quantitative pedology. New York: McGraw-Hill, 1941. 191p.

JONES, C.G.; LAWTON, J.H.; SHACHAK, M. Organisms as ecosystem engineers. Oikos, v.69, p.373-386, 1994.

JONGERIUS, A.; SCHELLING, J. Micromorphology of organic matter formed under the influence of soil organisms, especially soil fauna. International Society of Soil Science Congress, v.3, p.702-710, 1960.

LAVELLE, P. Ecological challenges for soil science. Soil Science, v.165, p.73-86, 2000.

LAVELLE, P. Faunal activities and soil processes: adaptive strategies that determine ecosystem function. Advances in Ecological Research, v.27, p.93-132, 1997.

LAVELLE, P. Functional domains in soils. Ecological Research, v.17, p.441-450, 2002.

LAVELLE, P.; DECAËNS, T.; AUBERT, M.; BAROT, S.; BLOUIN, M.; BUREAU, F.; MARGERIE, P.; MORA, P.; ROSSI, J.P. Soil invertebrates and ecosystem services. European Journal of Soil Biology, v.42, p.3-15, 2006.

LAVELlE, P.; LATTAUD, C.; TRIGO, D.; BAROIS, I. Mutualism and biodiversity in soils. Plant and Soil, v.170, p.23-33, 1995. 
LAVELLE, P.; SPAIN, A.V. Soil ecology. Amsterdam: Kluwer Scientific, 2001. 678p.

MARTINEZ, N.D.; WILLIAMS, R.J.; DUNNE, J.A. Diversity, complexity, and persistence in large model ecosystems. In: WORKSHOP FROM STRUCTURE TO DYNAMICS IN COMPLEX ECOLOGICAL NETWORKS, 2004, Santa Fe. Proceedings. New York: Oxford University, 2006. p.163-185.

MILLENNIUM ECOSYSTEM ASSESSMENT. Millennium Ecosystem Assessment [home page]. 2005. Available at: < http://www.maweb.org>. Accessed on: 11 Sept. 2009.

OMODEO, P. Particolarita della zoogeografia dei lombrichi. Bolletino di Zoologia, v.19, p.349-369, 1952.

SATCHELL, J.E. Earthworm ecology: from Darwin to vermiculture. London: Chapman \& Hall, 1983. 495p.
STERNER, R.W.; ELSER, J.J. Ecological stoichiometry: the biology of elements from molecules to the biosphere. Princeton: Princeton University, 2002. 438p.

SWIFT, M.J.; HEAL, O.W.; ANDERSON, J.M. Decomposition in terrestrial ecosystems. Oxford: Blackwell Scientific, 1979. 384p.

TARGULIAN, V.O.; KRASILNIKOV, P.V. Soil system and pedogenic processes: self-organization, time scales and environmental significance. Catena, v.71, p.373-381, 2007.

WALL, D.H.; MOORE, J.C. Interactions underground - soil biodiversity, mutualism, and ecosystem processes. Bioscience, v.49, p.109-117, 1999

WALLWORK, J.A. Ecology of soil animals. London: McGraw-Hill, 1970. 200p.

YOUNG, I.M.; CRAWFORD, J.W. Interactions and self-organization in the soil-microbe complex. Science, v.304, p.1634-1637, 2004.

Received on December 6, 2008 and accepted on July 8, 2009 